\title{
P06 - Pulmonary functions are affected during pollen season in children with allergic rhinitis
}

\author{
Süleyman Tolga Yavuz ${ }^{1 *}$, Mustafa Güleç², Osman Şener ${ }^{2}$ \\ From 3rd Pediatric Allergy and Asthma Meeting (PAAM) \\ Athens, Greece. 17-19 October 2013
}

\section{Background}

Along with the nasal symptoms, asthma-like symptoms, particularly cough, may also be present in children with pollen-induced allergic rhinitis during pollen season. The aim of this study was to evaluate whether patients with pollen-induced allergic rhinitis without a physician diagnosed asthma might, nevertheless, have airways obstruction both in and out of the pollen season.

\section{Method}

Patients with allergic rhinitis and grass pollen sensitization were evaluated both during and outside the pollen season. Allergic rhinitis diagnosis and severity grading were made according to ARIA guidelines. Skin prick tests, blood eosinophil counts and total IgE level measurements and pulmonary function tests (during and outside of pollen season) were performed in all subjects.

\section{Conclusion}

Pulmonary functions may be affected in children with pollen-induced allergic rhinitis during pollen season even if they have no history and symptoms of bronchial asthma.

\section{Authors' details}

'Department of Pediatric Allergy, Gulhane Military School of Medicine, Ankara, Turkey. ${ }^{2}$ Department of Adult Allergy and Clinical Immunology, Gulhane Military School of Medicine, Ankara, Turkey.

Published: 28 February 2014

doi:10.1186/2045-7022-4-S1-P61

Cite this article as: Yavuz et al.: P06 - Pulmonary functions are affected during pollen season in children with allergic rhinitis. Clinical and

Translational Allergy 2014 4(Suppl 1):P61.

\section{Results}

Thirty patients (17 male, 56.7\%) with a median age of 11.5 (8.7-13.6) years were included. 12 patients (40\%) had mild allergic rhinitis, whereas 18 (60\%) had moderate-persistent allergic rhinitis interfering with daily activities. There was no significant difference at spirometric parameters including forced vital capacity (FVC), forced expiratory volume at 1 second $\left(\mathrm{FEV}_{1}\right)$ and $\mathrm{FEV} 1 / \mathrm{FVC}$ ratio, which obtained in and out of pollen season. However, the forced expiratory flow between the 25 and $75 \%$ of the vital capacity $\left(\mathrm{FEF}_{25-75}\right)(100$ (91-96) vs. 91 (83-104)) and peak expiratory flow (PEF) (92 (83-97) vs. 82 (76-94)) values were significantly lower in pollen season when compared with the values obtained out of pollen season.

'Department of Pediatric Allergy, Gulhane Military School of Medicine, Ankara, Turkey

Full list of author information is available at the end of the article

Submit your next manuscript to BioMed Central and take full advantage of:

- Convenient online submission

- Thorough peer review

- No space constraints or color figure charges

- Immediate publication on acceptance

- Inclusion in PubMed, CAS, Scopus and Google Scholar

- Research which is freely available for redistribution 